\title{
The effect of 8-weeks wrestling training on unilateral muscle imbalances
}

\author{
Ali Tatlici ${ }^{1 \mathrm{ABDE}}$, Yavuz Lima ${ }^{2 \mathrm{CD}}$, Bekir Çiftçi ${ }^{1 \mathrm{CD}}$, Samet Aktas ${ }^{3 \mathrm{AD}}$, Tuğba Badak ${ }^{1 \mathrm{BD}}$ \\ ${ }^{1}$ Selçuk University, Turkey \\ ${ }^{2}$ Ballkesir Ataturk City Hospital, Turkey \\ ${ }^{3}$ Batman University, Turkey
}

Authors' Contribution: A - Study design; B - Data collection; C - Statistical analysis; D - Manuscript Preparation; E - Funds Collection.

\begin{abstract}
Purpose: $\quad$ This study aimed to investigate the effect of 8-weeks of wrestling training on unilateral muscle imbalances.

Material: $\quad$ Eight male elite Greco-Roman wrestlers (wrestling group) (age 21.25 $\quad 2.7$ years, height $176.6 \pm 6.8 \mathrm{~cm}$, body weight $81.00 \pm 9.3 \mathrm{~kg}$ ) and seven recreationally active male (control group) (age 21.3 \pm 3.2 years, height $173.6 \pm 4.7 \mathrm{~cm}$, body weight $67.3 \pm 5.3 \mathrm{~kg}$ ) voluntarily participated in the study. Both group participants were students in the Selcuk university in the period of study. Wrestlers were in the off-season before the training period of 10 weeks. Before and after the 8-weeks training period, wrestling and control groups were tested for isokinetic torque measurement. In the training period, the wrestling group carried out only wrestling training without specific strength training. In this period the control group did not involve in any exercise.

Results: In the wrestling group, all quadriceps torque parameters significantly increased for both legs but the torque parameters of the hamstring did not change, except the average torque of the left leg. The peak and average torque of the $\mathrm{H} / \mathrm{Q}$ (Hamstring/quadriceps) significantly decreased after training periods for right leg in the wrestling group. No parameters significantly changed in the control group.

Conclusions: Specific hamstring strength exercises can be put in training programs to avoid from a possible knee injury. Keywords: wrestling, strength imbalances, knee isokinetic strength
\end{abstract}

\section{Introduction}

Wrestling is one of the sports branches where muscle strength is most needed. Implementation of different proportions of action, such as pull, push and lift, during wrestling activities causes different physiological requirements for the athletes in this sport branch. Wrestling-specific movements show differences in the production of strength and in the produced strength, depending on which muscle group is used [1]. For example, in standing wrestling, the load on the support leg may be higher than the other leg during the pushing movement, or in the crotch lift movement, the duration of tension under an arm may be higher than for the other arm. These differences depending on the technique applied and can produce differences in body composition and strength values of wrestlers, and the basis of these differences are the muscle imbalances that play a crucial role in injuries.

The hamstring and quadriceps muscles groups from the lower extremity especially can have strength differences between each other, which are derived from athletic activities [2]. It has been reported many times that the strength imbalance is a factor that can seriously affect both athletic performance and injuries [3]. Additionally, it is known that each sports branch can have a specific effect on strength and strength imbalances. Although studies are reporting different effects of different strength training on strength imbalance [4], the effects of the sport branches and branch-specific training on the strength

\footnotetext{
(c) Ali Tatlici, Yavuz Lima, Bekir Çiftçi, Samet Aktas, Tuğba Badak, 2021 doi:10.15561/20755279.2021.0401
}

imbalance have had limited examination. Despite the fact that a $15 \%$ bilateral strength difference was accepted as a "strength imbalance" in the literature [5], according to the branches, the differences in this ratio make it possible to discuss the effects of strength imbalance on injuries or performance. In the football branch, hitting the ball with one leg and having the same leg on the ball at each repetition can give rise to strength difference to occur between the two legs $[6,7]$. At this point, it can not be said that high bilateral leg strength differences for the football branch are unexpected. In the same way, considering that the weightlifting branch is the maximum weight lifting sport with a balance, low bilateral leg strength differences may still occur [8]. Therefore, there is a need for studies examining the effects of training specific to branches on these strength imbalances. In parallel, it is also thought that wrestling training may have different effects on the unilateral strength balance in terms of content. This study aims to evaluate the lower extremity unilateral isokinetic strength of the elite wrestlers after 8 weeks of wrestling.

\section{Materials and Methods \\ Participants}

Eight male elite Greco-Roman wrestlers and seven healthy recreationally active male (control group) voluntarily participated in the study. All the participants were students of Selçuk University in the study period. Wrestlers attended national or international tournaments (at least once in the last 6 months). Elite wrestlers (age $21.25 \pm 2.7$ years, height $176.6 \pm 6.8 \mathrm{~cm}$, body $81.00 \pm 9.3$ 
$\mathrm{kg}$, all wrestlers dominant leg was right) were in the off-season for ten weeks. Active male participants (age $21.3 \pm 3.2$ years, height $173.6 \pm 4.7 \mathrm{~cm}$, body weight $67.3 \pm 5.3 \mathrm{~kg}$ ) did not involve in weight exercise 6 months prior to the second trial. Participants were informed about the aim and the risks of the study. All participants were provided with written informed consent. The study protocol was approved by the Ethics Committee of Selcuk University, Sport Sciences Faculty.

\section{Research Design}

Both groups were taken to the sports science faculty laboratory at 10:00 am. Participants were warned to not participate in any exercise in the past 48 hours until the end of the test section. Subjects were applied to a standard warm-up including stretching movements. Following that, participants were taken to isokinetic strength measurement by Cybex (Cybex NORM ${ }^{\circledR}$, Humac, CA, USA). After the first measurement, wrestlers started their wrestling training for eight weeks three times a week. The control group did not participate in any training or strong physical activity for the 8 -weeks period. 48 hours after the last wrestling training section, wrestlers and control groups were subjected to the second measurement of leg strength.

\section{Wrestling Training Program}

Wrestling-specific training and training matches were carried out for elite wrestlers for eight weeks. Each training session lasted 60-75 minutes. The wrestling training program did not contain any specific strength training with machines or gym training and this was managed by the trainer during 8-weeks.

\section{Isokinetic Knee Strength Measurement}

The isokinetic knee strength measurements were performed with an isokinetic dynamometer (Cybex, Humac Norm 2004) in the kinapometry laboratory of Selcuk University. Participants are seated in the correct position in the test seat. The participants' holders and the middle sections of the thighs were stabilized to the seat by the tapes. In addition, they were allowed to brace for support by holding the handles on the right and left sides of the seat during the test. The subjects were instructed to complete a $\mathrm{ROM}$ from $90^{\circ}$ to $10^{\circ}$. The point of the beginning was $90^{\circ}$ of flexion, then moving into extension.

Each subject was given a warm-up at $60^{\circ} \mathrm{sec}-1$ for 5 repetitions [9]. When the isokinetic warm-up was done, each subject had a 2-minute rest. After the rest period, each subject was asked to perform 5 repetitions as hard and as fast as he could at a speed of $60^{\circ}$ sec- 1 . Then, the test for the right leg was performed, then each subject was given a 5-minute rest, and then the procedure was repeated for the other leg [10]. Peak torque and average torque of both legs were recorded in Newton (Nm). Participants were supported by verbally encouraging expressions in order to achieve higher performance during the test.

\section{Statistical Analysis}

SPSS program (SPSS for Windows, version 24.0, SPSS Inc., Chicago, Illinois, USA) was used for statistical analyses. The data were presented as mean and standard deviation. Shapiro-Wilk test was used for normality; Levene's test was used for the homogeneity. Skewness and kurtosis values were checked for data sets that were not normally distributed, and those within \pm 2 were accepted to be normally distributed. Paired sample t-test was used to compare pre and post test parameters of groups. Effect size (Cohen d) and 95\% confidence intervals (CI) are included, together with $\mathrm{P}$ values, where appropriate. According to this formula, a d value of $<0.2$ was defined as weak effect size, a d value of 0.5 was defined as moderate, and a $\mathrm{d}$ value of $>0.8$ was defined as strong effect size. Statistical results were assessed within $95 \%$ confidence interval and at a significance level of $\mathrm{p}<0.05$.

\section{Results}

Table 1 shows that the peak torque extension of the wrestling group significantly increased after the training period. Also, the average extension torque of the wrestling group increased significantly. There was no statistical difference between the pre and post-test of the wrestling group for other parameters. The control group did not show any statistical differences after the 8-weeks period for isokinetic output. When the $\mathrm{H} / \mathrm{Q}$ ratio is evaluated, peak torque and average torque of wrestlers reduced significantly.

In table 2 , it is seen that the peak torque extension, the average extension torque and the average flexion torque of the wrestling group significantly increased after the training period. There was no statistical difference in peak torque flexion between the pre and post-test of the wrestling group. The control group did not show any statistical differences after the 8 -weeks period for

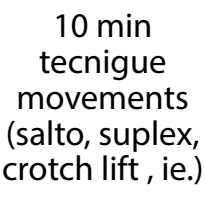

2 min pull-push (80-90\%) for 4-5 times with $1 \mathrm{~min}$ rest

$\begin{array}{cc}15-20 \text { min } & (80-90 \%) \\ \text { warm and up } & \text { times with } 1 \text { min } \\ \text { stretching } & \text { rest }\end{array}$

\begin{tabular}{|c|c|c|}
\hline $\begin{array}{l}20 \text { min }(50-60 \%) \\
\text { warm up with } \\
\text { pair by wrestling }\end{array}$ & $\begin{array}{l}\text { 3-5 times } \\
\text { wrestling } \\
\text { match }\end{array}$ & $\begin{array}{c}10 \text { min cool } \\
\text { down }\end{array}$ \\
\hline
\end{tabular}

Figure 1. Wrestling Training Pattern 
Table 1. Right leg pre and post-test isokinetic torque outputs of wrestling and control groups

\begin{tabular}{|c|c|c|c|c|c|c|c|c|}
\hline $\begin{array}{l}\text { Variables } \\
(\mathrm{Nm})\end{array}$ & $\begin{array}{l}\text { Pre and } \\
\text { Post test }\end{array}$ & $\mathbf{N}$ & Mean & S.D & $\mathbf{t}$ & $95 \% \mathrm{Cl}$ & $\mathbf{P}$ & E.S \\
\hline \multirow{3}{*}{ PP Ext } & $\begin{array}{l}\text { Wrestling } \\
\text { Pre-Test }\end{array}$ & 8 & 242.00 & 21.69 & \multirow{3}{*}{-3.88} & \multirow{3}{*}{$-32.97--8.02$} & \multirow{3}{*}{$* 0.006$} & \multirow{3}{*}{1.37} \\
\hline & & & & & & & & \\
\hline & $\begin{array}{l}\text { Wrestilng } \\
\text { post-Test }\end{array}$ & 8 & 262.50 & 27.83 & & & & \\
\hline \multirow{3}{*}{ PP Flex } & $\begin{array}{l}\text { Wrestling } \\
\text { Pre-Test }\end{array}$ & 8 & 141.88 & 19.75 & \multirow{3}{*}{1.15} & \multirow{3}{*}{$-6.19-17.95$} & \multirow{3}{*}{0.288} & \multirow{3}{*}{0.41} \\
\hline & Wrestling & & & & & & & \\
\hline & post-Test & 8 & 136.000 & 24.23 & & & & \\
\hline \multirow{2}{*}{ Avg Ext } & $\begin{array}{l}\text { Wrestling } \\
\text { Pre-Test }\end{array}$ & 8 & 163.88 & 19.12 & \multirow{2}{*}{-3.71} & \multirow[b]{2}{*}{$-27.83--6.16$} & \multirow{2}{*}{$* 0.008$} & \multirow[b]{2}{*}{1.31} \\
\hline & $\begin{array}{l}\text { Wrestling } \\
\text { post-Test }\end{array}$ & 8 & 180.88 & 23.85 & & & & \\
\hline \multirow{2}{*}{ Avg Flex } & $\begin{array}{l}\text { Wrestling } \\
\text { Pre-Test }\end{array}$ & 8 & 105.63 & 10.25 & \multirow{2}{*}{-0.75} & \multirow{2}{*}{$-7.25-3.75$} & \multirow{2}{*}{0.477} & \multirow{2}{*}{0.27} \\
\hline & $\begin{array}{l}\text { Wrestling } \\
\text { post-Test }\end{array}$ & 8 & 107.38 & 14.30 & & & & \\
\hline \multirow{2}{*}{$H_{p p} / Q_{p p}$} & $\begin{array}{l}\text { Wrestling } \\
\text { Pre-Test }\end{array}$ & 8 & 0.58 & 0.06 & \multirow{2}{*}{3.33} & \multirow{2}{*}{$0.01-0.11$} & \multirow{2}{*}{$* 0.013$} & \multirow{2}{*}{1.18} \\
\hline & $\begin{array}{l}\text { Wrestling } \\
\text { post-Test }\end{array}$ & 8 & 0.52 & 0.10 & & & & \\
\hline \multirow[b]{2}{*}{$\mathbf{H}_{\text {Avg } /} \mathbf{Q}_{\text {Avg }}$} & $\begin{array}{l}\text { Wrestling } \\
\text { Pre-Test }\end{array}$ & 8 & 0.65 & 0.09 & \multirow{2}{*}{2.60} & \multirow{2}{*}{$0.00-0.09$} & \multirow{2}{*}{$* 0.035$} & \multirow{2}{*}{0.92} \\
\hline & $\begin{array}{l}\text { Wrestling } \\
\text { post-Test }\end{array}$ & 8 & 0.60 & 0.08 & & & & \\
\hline \multirow{2}{*}{ PP Ext } & $\begin{array}{l}\text { Control Pre- } \\
\text { Test }\end{array}$ & 7 & 207.71 & 40.98 & & & & \\
\hline & $\begin{array}{l}\text { Control } \\
\text { post-Test }\end{array}$ & 7 & 209.14 & 36.13 & -0.584 & $-1.41-4.56$ & 0.581 & $1.3 /$ \\
\hline PP Flex & $\begin{array}{l}\text { Control Pre- } \\
\text { Test }\end{array}$ & 7 & 114.86 & 22.35 & -0885 & $-699-327$ & 0.410 & 0.41 \\
\hline rtice & $\begin{array}{l}\text { Control } \\
\text { post-Test }\end{array}$ & 7 & 116.71 & 22.32 & ك. & 1.5. & 0.410 & 0.41 \\
\hline Avg & $\begin{array}{l}\text { Control Pre- } \\
\text { Test }\end{array}$ & 7 & 140.00 & 28.23 & & & 0.464 & 131 \\
\hline Avg EXt & $\begin{array}{l}\text { Control } \\
\text { post-Test }\end{array}$ & 7 & 141.57 & 30.97 & -0.182 & $-6.49-3.34$ & 0.464 & 1.31 \\
\hline & $\begin{array}{l}\text { Control Pre- } \\
\text { Test }\end{array}$ & 7 & 90.43 & 17.03 & & & & דר 0 \\
\hline Avg Flex & $\begin{array}{l}\text { Control } \\
\text { post-Test }\end{array}$ & 7 & 92.14 & 16.99 & -0.962 & $-6.0 /-2.64$ & $0.3 / 3$ & 0.21 \\
\hline & $\begin{array}{l}\text { Control Pre- } \\
\text { Test }\end{array}$ & 7 & .55 & 0.09 & & & & \\
\hline$H_{p p} / Q_{p p}$ & $\begin{array}{l}\text { Control } \\
\text { post-Test }\end{array}$ & 7 & .56 & 0.08 & -0.280 & $-.026-0.021$ & 0.789 & 1.18 \\
\hline & $\begin{array}{l}\text { Control Pre- } \\
\text { Test }\end{array}$ & 7 & .65 & 0.13 & & & & \\
\hline $\mathbf{H}_{\text {Avg } /} \mathbf{Q}_{\text {Avg }}$ & $\begin{array}{l}\text { Control } \\
\text { post-Test }\end{array}$ & 7 & .66 & 0.12 & -0.458 & $-0.03-0.02$ & 0.663 & 0.92 \\
\hline
\end{tabular}

PP Ext= Peak torque extension; PP Flex= Peak torque flexion; Avg Ext= Average torque extension; Avg Flex=Average torque flexion; $\mathbf{H}_{\mathrm{pp}} / \mathbf{Q}_{\mathrm{pp}}=$ Hamstring/quadriceps peak torque ratio; $\mathbf{H}_{\mathrm{pp}} / \mathbf{Q}_{\mathrm{pp}}=$ Hamstring/quadriceps average torque ratio. 95\% Cl: Confidence interval. E.S: Cohen's d effect size. *Significant difference. $\mathrm{P}<0.05$. 
Table 2. Left leg pre and post-test isokinetic torque outputs of wrestling and control groups

\begin{tabular}{|c|c|c|c|c|c|c|c|c|}
\hline $\begin{array}{l}\text { Variables } \\
(\mathrm{Nm})\end{array}$ & $\begin{array}{l}\text { Pre and } \\
\text { post test }\end{array}$ & $\mathbf{N}$ & Mean & S.D & $t$ & $95 \% \mathrm{Cl}$ & $\mathbf{P}$ & E.S \\
\hline \multirow{4}{*}{ PP Ext } & Wrestling & & & & \multirow{4}{*}{-3.09} & \multirow{4}{*}{$-26.68--3.56$} & \multirow{4}{*}{ *0.017 } & \multirow{4}{*}{1.09} \\
\hline & Pre-Test & 8 & 242.88 & 32.75 & & & & \\
\hline & post-Test & & & & & & & \\
\hline & $\begin{array}{l}\text { Wrestling } \\
\text { post-Test }\end{array}$ & 8 & 258.00 & 32.92 & & & & \\
\hline \multirow[b]{2}{*}{ PP Flex } & $\begin{array}{l}\text { Wrestling } \\
\text { Pre-Test }\end{array}$ & 8 & 123.75 & 8.90 & \multirow[b]{2}{*}{-1.14} & \multirow[b]{2}{*}{$-24.87-8.62$} & \multirow[b]{2}{*}{0.289} & \multirow[b]{2}{*}{0.41} \\
\hline & $\begin{array}{l}\text { Wrestling } \\
\text { post-Test }\end{array}$ & 8 & 131.88 & 25.38 & & & & \\
\hline \multirow{2}{*}{ Avg Ext } & $\begin{array}{l}\text { Wrestling } \\
\text { Pre-Test }\end{array}$ & 8 & 165.00 & 20.42 & \multirow{2}{*}{-3.83} & \multirow{2}{*}{$-20.40--4.84$} & \multirow{2}{*}{$* 0.006$} & \multirow{2}{*}{1.36} \\
\hline & $\begin{array}{l}\text { Wrestling } \\
\text { post-Test }\end{array}$ & 8 & 177.63 & 24.64 & & & & \\
\hline \multirow{2}{*}{ Avg Flex } & $\begin{array}{l}\text { Wrestling } \\
\text { Pre-Test }\end{array}$ & 8 & 95.63 & 11.32 & \multirow{2}{*}{-2.42} & \multirow{2}{*}{$-12.58--0.16$} & \multirow{2}{*}{$* 0.046$} & \multirow{2}{*}{0.86} \\
\hline & $\begin{array}{l}\text { Wrestling } \\
\text { post-Test }\end{array}$ & 8 & 102.00 & 17.58 & & & & \\
\hline \multirow[b]{2}{*}{$H_{p p} / Q_{p p}$} & $\begin{array}{l}\text { Wrestling } \\
\text { Pre-Test }\end{array}$ & 8 & 0.51 & 0.07 & \multirow{2}{*}{0.17} & \multirow{2}{*}{$-.06-0.06$} & \multirow{2}{*}{0.865} & \multirow[b]{2}{*}{0.06} \\
\hline & $\begin{array}{l}\text { Wrestling } \\
\text { post-Test }\end{array}$ & 8 & 0.51 & 0.07 & & & & \\
\hline \multirow{2}{*}{$\mathrm{H}_{\text {Avg } /} \mathrm{Q}_{\text {Avg }}$} & $\begin{array}{l}\text { Wrestling } \\
\text { Pre-Test }\end{array}$ & 8 & 0.58 & .09 & \multirow{2}{*}{0.33} & \multirow{2}{*}{$-0.03-0.04$} & \multirow{2}{*}{0.751} & \multirow{2}{*}{0.12} \\
\hline & $\begin{array}{l}\text { Wrestling } \\
\text { post-Test }\end{array}$ & 8 & 0.58 & 0.11 & & & & \\
\hline \multirow{2}{*}{ PP Ext } & $\begin{array}{l}\text { Control } \\
\text { Pre-Test }\end{array}$ & 7 & 201.86 & 29.22 & & & & \\
\hline & $\begin{array}{l}\text { Control } \\
\text { post-Test }\end{array}$ & 7 & 201.29 & 25.49 & 0.30 & $-4.04-5.19$ & $0.1 / 2$ & 0.11 \\
\hline & $\begin{array}{l}\text { Control } \\
\text { Pre-Test }\end{array}$ & 7 & 114.29 & 19.31 & & & & \\
\hline PP Flex & $\begin{array}{l}\text { Control } \\
\text { post-Test }\end{array}$ & 7 & 115.86 & 19.50 & -0.69 & $-7.09-3.94$ & 0.512 & 0.25 \\
\hline & $\begin{array}{l}\text { Control } \\
\text { Pre-Test }\end{array}$ & 7 & 137.29 & 18.01 & & & & \\
\hline Avg Ext & $\begin{array}{l}\text { Control } \\
\text { post-Test }\end{array}$ & 7 & 138.00 & 20.65 & -0.26 & $-7.29-5.86$ & 0.799 & 0.09 \\
\hline Avg Flex & $\begin{array}{l}\text { Control } \\
\text { Pre-Test }\end{array}$ & 7 & 80.43 & 15.78 & -089 & $-587-272$ & 0.406 & \\
\hline Avg riex & $\begin{array}{l}\text { Control } \\
\text { post-Test }\end{array}$ & 7 & 82.00 & 14.31 & -0.89 & $-5.8 /-2.12$ & 0.406 & 0.32 \\
\hline & $\begin{array}{l}\text { Control } \\
\text { Pre-Test }\end{array}$ & 7 & 0.57 & 0.10 & & & & \\
\hline$H_{p p} / Q_{p p}$ & $\begin{array}{l}\text { Control } \\
\text { post-Test }\end{array}$ & 7 & 0.57 & 0.08 & -0.36 & $-0.04-0.03$ & 0.132 & 0.13 \\
\hline & $\begin{array}{l}\text { Control } \\
\text { Pre-Test }\end{array}$ & 7 & 0.59 & 0.13 & & & & \\
\hline $\mathbf{H}_{\text {Avg } /} \mathbf{Q}_{\text {Avg }}$ & $\begin{array}{l}\text { Control } \\
\text { post-Test }\end{array}$ & 7 & 0.60 & 0.12 & -0.61 & $-0.04-0.02$ & 0.559 & 0.22 \\
\hline
\end{tabular}

PP Ext= Peak torque extension; PP Flex= Peak torque flexion; Avg Ext= Average torque extension; Avg Flex=Average torque flexion; $\mathbf{H}_{\mathrm{pp}} / \mathbf{Q}_{\mathrm{pp}}=$ Hamstring/quadriceps peak torque ratio; $\mathbf{H}_{\mathrm{pp}} / \mathbf{Q}_{\mathrm{pp}}=$ Hamstring/quadriceps average torque ratio. $95 \% \mathrm{Cl}$ : Confidence interval. E.S: Cohen's d effect size. *Significant difference. $\mathrm{P}<0.05$. 
isokinetic output. The $\mathrm{H} / \mathrm{Q}$ ratio did not significantly change for both groups for the left leg.

\section{Discussion}

To our knowledge, this study is the first study in the literature to evaluate the effect of long-term wrestlingspecific training on the strength of the thigh muscles. In this study, while long-term wrestling-specific training did not cause a significant difference in hamstring muscle strength, it made a significant difference in quadriceps muscle strength and resulted in reduced H/Q ratio.

Several studies reported the incidences and characteristics of injuries in male wrestling athletes [11, 12, 13]. While Jarret et al. [12] reported that the incidence of injury was 9.6 injuries / 1, 000 hours in collegiate wrestling, Yard et al. [11] reported 7.25 injuries / 1, 000 hours in collegiate wrestling and 2.33 injuries / 1, 000 hours in high school wrestling. When the injury locations are examined, the two most frequently injured locations are the knee (17-24.8\%) and shoulder (17.8-24\%) joints and the injury types were often sprains $(22.6-28 \%)$ and strains $(30.6 \%)[11,12,13]$. The knee injuries were not only often but also severe. Surgical treatment may be required and it takes a long time for athletes to return to pre-injury levels [14]. Therefore, the injury mechanism and predisposing factors should be examined and necessary protective measures should be taken [15].

Predisposing factors are divided into two groups intrinsic and extrinsic. While age, gender, muscle strength imbalance, flexibility and proprioception problems, and surgery history are intrinsic factors, ground, protective equipment (such as helmet, mask, shin splint) are extrinsic [16]. Muscle strength imbalance is one of the most important predisposing factors. It also affects other factors such as flexibility, proprioception, and ground force, and it becomes more important in sports branches that include repetitive jumps, a sudden change of direction and acceleration-deceleration motion patterns [17]. It is recommended that $\mathrm{H} / \mathrm{Q}$ conventional ratios should be 0.6 or above in order to prevent the thigh muscle imbalance and lower extremity injuries, especially of the knee joint $[18,19]$. In our study, wrestling athletes performed wrestling-specific training for 8 weeks without doing strength training; peak torque and average torque values in both thigh extensor muscles and the average torque in the left knee flexor muscles increased significantly. However, when the H/Q ratio was evaluated, a significant decrease was observed in the right thigh peak torque and average torque $(p=0.013 ; p=0.004$, respectively). The quadriceps muscle strength may increase more because of wrestling-specific training which includes repetitively pushing the opponent. Wrestling-specific training reduces the $\mathrm{H} / \mathrm{Q}$ concentric muscle strength rate and may increase the incidence of knee injuries. Considering the characteristics of wrestling sports injury, thigh muscle strength imbalance caused by performing specific training should be eliminated.

When the subgroups of injuries in wrestling athletes are evaluated, they are reported in the knee joint as a proportion of $17-24.8 \%[11,13]$. Considering the severity of various injuries, knee injuries are the most important injuries. This is also because $44 \%$ of season-ending injuries were in the knee joint [13]. Most of the severe knee injuries are anterior cruciate ligament (ACL) based. In addition, the possibility of not being able to return to sports at the pre-injury level after the ACL injury, and the risk of re-rupture and injury of the other structures in the knee (other ligaments, meniscus, cartilage) makes the subject even more important. Predisposing factors should therefore be identified and eliminated before the injury occurs.

It was reported many times that approximately $70 \%$ of ACL injuries occur during non-contact and the most common mechanism of injury is external valgus and femoral rotation $[14,16,17,20,21]$. Also known as "knee in-toe out", this mechanism is followed by an anterior tibial translation [22]. Excessive quadriceps activity and varus torque are also other injury mechanisms [23, 24]. However, when we examine the knee injuries in wrestling, it is reported that the most common injury positions were takedown and sparring (68\% and $18.4 \%$ respectively) $[11,13]$. An ACL injury occurs when the total vector of intrinsic and extrinsic risk factors and severity of the injury is greater than the tolerance of dynamic stabilizers on the knee and anterior cruciate ligament tension [25]. Withrow et. al reported that the increase in hamstring muscle strength reduces ligament injuries by decreasing the load on the ACL, and also that increased muscle strength in quadriceps increases the risk of ACL injury [26]. Lloyd and Buchanan [27] reported that the increase in $\mathrm{H} / \mathrm{Q}$ ratio in the biomechanical model knee does not only decrease tibial anterior translation, but it also reduces external valgus and femoral rotation. According to the results obtained in our study, it can be said that the muscle imbalance caused by wrestling-specific training facilitates all the injury mechanisms of ACL (especially excessive quadriceps activity).

On the other hand, Hewett et al. [24] performed long-term plyometric training in female athletes and observed that the hamstring muscle strength increased and the reaction force of the ground also decreased significantly. The increase in hamstring muscle strength not only regulates the intrinsic factors but can also reduce the likelihood of knee injury by providing relative improvement in the extrinsic predisposing factor such as the ground force. In this context, the decrease in H/Q ratio may increase the possibility of injury by increasing ground reaction force, especially in sports branches in which repetitive jumps are frequent.

The imbalance in H/Q muscle strength ratio does not only increase the possibility of ACL injury. At the same time, other structures in and around the knee joint also can be injured easier. For example, external meniscus tears, collateral ligaments, and femoral lateral condyle cartilage damage may accompany ACL injuries frequently [28]. In addition, the decrease in functional $\mathrm{H} / \mathrm{Q}$ ratio increases the likelihood of hamstring muscle injuries, especially in sports branches with repetitive sprints; hamstring 
strengthening exercise may reduce the incidence and severity of hamstring muscle injuries [29]. On the other hand, in accordance with the results obtained in our study, wrestling-specific training also increases the load on the anterior knee and increases the likelihood of overuse injuries, such as patellofemoral joint problems, quadriceps and patellar tendinopathy, and infrapatellar bursitis.

One of the most important things to provide the function of joint stability is co-activation between agonist and antagonist muscle groups. Hamstring and quadriceps co-activation is the functional component that limits all excessive knee movements, prevents overload the structure of the knee and helps maintain dynamic stability [30]. Lloyd and Buchanan reported that co-activation was $11-14 \%$ protective against external varus and the valgus moment [27]. The decrease in $\mathrm{H} / \mathrm{Q}$ muscle strength ratio also reduces the effectiveness of these protective mechanisms and may increase the incidence and severity of injuries.

There are some limitations to this study. Firstly, the participants were few. The results of the study with more participants may be different. Secondly, injuries and symptoms in athletes were not followed up. Lastly, we measured the conventional $\mathrm{H} / \mathrm{Q}$ ratio at 60 degrees angular velocity. It may be more useful to measure the functional $\mathrm{H} / \mathrm{Q}$ ratio at higher angular velocities.

\section{Conclusions}

Wrestling specific training may increase the likelihood of knee injuries, especially ACL, by reducing $\mathrm{H} / \mathrm{Q}$ muscle strength ratio. The imbalance caused by specific training should be eliminated especially by hamstring eccentric strength and proprioception training.

\section{Acknowledgments}

The authors sincerely thank the subjects, who participated in this study and contributed to the realization of this study. This research received no funding.

\section{Conflicts of Interest}

The authors declare no conflict of interest.

\section{References}

1. Horswill CA. Applied Physiology of Amateur Wrestling. Sports Medicine, 1992;14:114-43. https://doi.org/10.2165/00007256-199214020-00004

2. Daneshjoo A, Rahnama N, Mokhtar AH, Yusof A. Bilateral and Unilateral Asymmetries of Isokinetic Strength and Flexibility in Male Young Professional Soccer Players. Journal of Human Kinetics, 2013;36:45-53. https://doi.org/10.2478/hukin-2013-0005

3. Impellizzeri FM, Bizzini M, Rampinini E, Cereda F, Maffiuletti NA. Reliability of isokinetic strength imbalance ratios measured using the Cybex NORM dynamometer. Clin Physiol Funct Imaging, 2008;28:113-9. https://doi.org/10.1111/j.1475-097X.2007.00786.x

4. Gioftsidou A, Ispirlidis I, Pafis G, Malliou P, Bikos C, Godolias G. Isokinetic strength training program for muscular imbalances in professional soccer players. Sport Sci Health, 2008;2:101-5. https://doi.org/10.1007/s11332-008-0047-5

5. Cheung R, Smith A, Wong D. H:Q Ratios and Bilateral Leg Strength in College Field and Court Sports Players. Journal of Human Kinetics, 2012;33:63-71. https://doi.org/10.2478/v10078-012-0045-1

6. Fousekis K, Tsepis E, Vagenas G. Lower limb strength in professional soccer players: profile, asymmetry, and training age. Journal of Sports Science \& Medicine, 2010;9(3):364.

7. Kellis S, Gerodimos V, Kellis E, Manou V. Bilateral isokinetic concentric and eccentric strength profiles of the knee extensors and flexors in young soccer players. Isokinetics and Exercise Science, 2001;9:31-9. https://doi.org/10.3233/IES-2001-0061

8. Kang SH, Kim CW, Kim YI, Kim KB, Lee SS, Shin K ok. Alterations of Muscular Strength and Left and Right Limb Balance in Weightlifters after an 8-week Balance Training Program. J Phys Ther Sci, 2013;25:895-900. https://doi.org/10.1589/jpts.25.895

9. Brown LE. Isokinetics in human performance. Human Kinetics; 2000.

10.Rossi MD, Brown LE, Whitehurst M, Charni C, Hankins J, TaylorCL.Comparisonofkneeextensorstrengthbetweenlimbs in individuals with bilateral total knee replacement. Archives of Physical Medicine and Rehabilitation, 2002;83:523-6. https://doi.org/10.1053/apmr.2002.30935

11. Yard EE, Collins CL, Dick RW, Comstock RD. An Epidemiologic Comparison of High School and College Wrestling Injuries. Am J Sports Med, 2008;36:57-64. https://doi.org/10.1177/0363546507307507

12.Jarrett GJ, Orwin JF, Dick RW. Injuries in Collegiate Wrestling. Am J Sports Med, 1998;26:674-80. https://doi.org/10.1177/03635465980260051301

13.Pasque CB, Hewett TE. A Prospective Study of High School Wrestling Injuries < sup/>. Am J Sports Med 2000;28:509-15. https://doi.org/10.1177/03635465000280041101

14.Myklebust G. Return to play guidelines after anterior cruciate ligament surgery. British Journal of Sports Medicine, 2005;39:127-31. https://doi.org/10.1136/bjsm.2004.010900

15.van Mechelen W, Hlobil H, Kemper HCG. Incidence, Severity, Aetiology and Prevention of Sports Injuries: A Review of Concepts. Sports Medicine, 1992;14:82-99. https://doi.org/10.2165/00007256-199214020-00002

16.Bahr R. Understanding injury mechanisms: a key component of preventing injuries in sport. British Journal of Sports Medicine, 2005;39:324-9. https://doi.org/10.1136/bjsm.2005.018341

17.Kirkendall DT, Garrett WE. The Anterior Cruciate Ligament Enigma: Injury Mechanisms and Prevention. Clinical Orthopaedics and Related Research, 2000;372:64-8. https://doi.org/10.1097/00003086-200003000-00008

18.Coombs R, Garbutt G. Developments in the use of the hamstring/quadriceps ratio for the assessment of muscle balance. Journal of Sports Science \& Medicine, 2002;1(3):56.

19.Holcomb WR, Rubley MD, Lee HJ, Guadagnoli MA. Effect of Hamstring-Emphasized Resistance Training on Hamstring:Quadriceps Strength Ratios. J Strength Cond Res, 2007;21:41. https://doi.org/10.1519/R-18795.1

20.McLean SG, Huang X, Su A, van den Bogert AJ. Sagittal plane biomechanics cannot injure the ACL during sidestep cutting. Clinical Biomechanics, 2004;19:828-38. 
https://doi.org/10.1016/j.clinbiomech.2004.06.006

21.Yu B, Garrett WE. Mechanisms of non-contact ACL injuries. British Journal of Sports Medicine, 2007;41:i47-51. https://doi.org/10.1136/bjsm.2007.037192

22.Kobayashi H, Kanamura T, Koshida S, Miyashita K, Okado $\mathrm{T}$, Shimizu T, et al. Mechanisms of the anterior cruciate ligament injury in sports activities: a twenty-year clinical research of 1,700 athletes. J Sports Sci Med, 2010;9:669-75.

23.Demorat G, Weinhold P, Blackburn T, Chudik S, Garrett W. Aggressive Quadriceps Loading Can Induce Noncontact Anterior Cruciate Ligament Injury. $A m \quad J$ Sports Med, 2004;32:477-83. https://doi.org/10.1177/0363546503258928

24.Hewett TE, Stroupe AL, Nance TA, Noyes FR. Plyometric Training in Female Athletes: Decreased Impact Forces and Increased Hamstring Torques. Am J Sports Med, 1996;24:765-73. https://doi.org/10.1177/036354659602400611

25.Meeuwisse WH. Assessing Causation in Sport Injury: A Multifactorial Model. Clinical Journal of Sport Medicine, 1994;4:166-70. https://doi.org/10.1097/00042752-199407000-00004

26. Withrow TJ, Huston LJ, Wojtys EM, Ashton-Miller
JA. Effect of Varying Hamstring Tension on Anterior Cruciate Ligament Strain During in Vitro Impulsive Knee Flexion and Compression Loading: The Journal of Bone and Joint Surgery-American Volume, 2008;90:815-23. https://doi.org/10.2106/JBJS.F.01352

27.Lloyd DG, Buchanan TS. Strategies of muscular support of varus and valgus isometric loads at the human knee. Journal of Biomechanics, 2001;34:1257-67. https://doi.org/10.1016/S0021-9290(01)00095-1

28.Cerabona F, Sherman MF, Bonamo JR, Sklar J. Patterns of meniscal injury with acute anterior cruciate ligament tears. Am J Sports Med, 1988;16:603-9. https://doi.org/10.1177/036354658801600609

29.Brooks JHM, Fuller CW, Kemp SPT, Reddin DB. Incidence, Risk, and Prevention of Hamstring Muscle Injuries in Professional Rugby Union. Am J Sports Med, 2006;34:1297-306. https://doi.org/10.1177/0363546505286022

30.Ford KR, van den Bogert J, Myer GD, Shapiro R, Hewett TE. The effects of age and skill level on knee musculature co-contraction during functional activities: a systematic review. British Journal of Sports Medicine, 2008;42:561-6. https://doi.org/10.1136/bjsm.2007.044883

\section{Information about the authors:}

Ali Tatlici; (Corresponding Author); Res. Asst; http://orcid.org/0000-0001-6346-0010; alitatlici@selcuk.edu.tr; Faculty of Sports Science, Selçuk University; Konya, 42130, Turkey.

Yavuz Lima; Sports Medicine Specialist; http://orcid.org/0000-0001-5429-1905; yavuzlymma@gmail.com; Sport medicine clinic, Balıkesir Ataturk city hospital, Balıkesir, Turkey

Bekir Çiftçi; Res. Asst; http://orcid.org/0000-0002-0362-6186; ciftcibekir81@gmail.com; Faculty of Sports Science, Selçuk University; Konya, 42130, Turkey.

Samet Aktas; Assc. Professor; http://orcid.org/0000-0001-6857-2599; sametaktas85@hotmail.com; Batman University, High school of Physical Education and Sports, Konya, Turkey.

Tuğba Badak; Doctorate Student; http://orcid.org/0000-0002-9306-0760; tugbadak1@gmail.com; Faculty of Sports Science Selçuk University; Konya, 42130, Turkey.

\section{Cite this article as:}

Tatlici A, Lima Y, Çiftçi B, Aktas S, Badak T. The effect of 8-weeks wrestling training on unilateral muscle imbalances. Physical Education of Students, 2021;25(4):205-211. https://doi.org/10.15561/20755279.2021.0401

This is an Open Access article distributed under the terms of the Creative Commons Attribution License, which permits unrestricted use, distribution, and reproduction in any medium, provided the original work is properly cited http://creativecommons.org/licenses/by/4.0/deed.en

Received: 25.08 .2020

Accepted: 30.09.2020; Published: 30.08.2021 